\title{
CHROMIUM(VI) REMOVAL USING ACTIVATED THUJA OCCIDENTALIS LEAVES CARBON POWDER - ADSORPTION ISOTHERMS AND KINETIC STUDIES
}

\author{
Vaddi Dhilleswara Rao ${ }^{1,}{ }^{凶}$, Mushini Venkata Subba Rao ${ }^{1}$, M.P.S.Murali Krishna ${ }^{2}$
}

https://doi.org/10.23939/chcht14.03.362

\begin{abstract}
This study investigates the capability of Thuja occidentalis leaves carbon powder (TOLC) as a viable adsorbent for the expulsion of chromium(VI) from aqueous solutions. By batch mode, the removal percentage of $\mathrm{Cr}(\mathrm{VI})$ is observed to be $\mathrm{pH}$ perceptive and furthermore relies upon the time of equilibration, amount of the TOLC adsorbent and $\mathrm{Cr}(\mathrm{VI})$ concentration. TOLC adsorbent before and after adsorption of $\mathrm{Cr}(\mathrm{VI})$ was characterized with FTIR, SEM and EDX. Adsorption isotherm results divulge that the Langmuir model was a better fit. The kinetic studies divulge that the pseudosecond-order model was the best fit. TOLC adsorbent can be easily regenerated and utilised for several adsorption/ desorption cycles.
\end{abstract}

Keywords: Thuja occidentalis leaves, $\mathrm{Cr}(\mathrm{VI})$ adsorption, adsorption isotherm, kinetics.

\section{Introduction}

Eco-harmfulness to living beings has turned into a prime worry in the last couple of decades. Due to increasing urbanisation and additionally industrialisation [1], a large number of contaminants, mainly heavy metals, are generated. The heavy metals, viz., $\mathrm{Cr}, \mathrm{Cd}, \mathrm{Ni}, \mathrm{As}, \mathrm{Cu}$, $\mathrm{Pb}$, etc. draw widespread attention due to persistent character, toxicity and carcinogenic nature even in lesser amounts [2]. The most important sources of heavy metals are electroplating industries, mining industries, metal plating industries, tannery effluents, etc. The introduction of industrial effluents having these heavy metals into natural water resources is a reason of severe ecological problems [3], since the discharged industrial effluents also contaminate the groundwater [4]. One of such dangerous heavy metal is chromium, arising due to the use of toxic chromium salts in leather, metal cleaning, tannery and

\footnotetext{
${ }^{1}$ G M R Institute of Technology, affiliated to JNTUK, Rajam, A.P, India

${ }^{2}$ Department of Chemistry, Andhra Polytechnic, Kakinada 533003, A.P, India

$凶$ dhilleswararao.v@gmrit.edu.in

(c) Rao VD, Rao MVS, Krishna M., 2020
}

metallurgical industries, paints, wood preservatives and ceramics [5]. The chromium metal exits in the hexavalent and trivalent forms in water. $\mathrm{Cr}(\mathrm{VI})$ is considered more perilous mainly due to its carcinogenic nature [6] and is 100 times more toxic than $\mathrm{Cr}(\mathrm{III})$ ion due to its high aqueous solubility and easy accumulation and absorption in stomach, kidneys and liver [7]. Exposure of $\mathrm{Cr}(\mathrm{VI})$ in humans has been connected with a variety of respiratory diseases, respiratory tract disorders, allergies and lung carcinoma [8, 9]. Depending on the solution $\mathrm{pH}$, chromium exits in solution in anionic forms as $\mathrm{CrO}_{4}{ }^{2-}$, $\mathrm{Cr}_{2} \mathrm{O}_{7}{ }^{2-}, \mathrm{HCrO}_{4}^{-}, \mathrm{Cr}_{4} \mathrm{O}_{13}{ }^{2-}$ and neutral form as $\mathrm{H}_{2} \mathrm{CrO}_{4}$ [10]. The maximum allowable concentration of chromium in drinking water, as per the recommendations of WHO (World Health Organisation) and US-EPA (United StatesEnvironmental Protection Agency), is 0.05 and $0.1 \mathrm{mg} / \mathrm{l}$, respectively $[11,12]$. Hence, increasing ecological awareness attached with strict regulation standards has triggered different industries to confront themselves looking for suitable wastewater treatment methods [13].

Several technologies (precipitation, electrochemical treatment, filtration membrane, ion exchange method) have been adopted for the expulsion of chromium metal ion from waste water $[4,14]$. However, these technologies have some drawbacks, such as low selectivity, expensiveness, incomplete metal removal, high energy requirements, etc. The adsorption strategy using an adsorbent is a reasonably new process and is developing as a favoured option since it gives easy operation, high-quality treated effluent, high efficiency, low cost. The used adsorbent can be regenerated several times and regenerated material is used for the conversion of heavy metal contaminated water to heavy metal free water in order to obtain environmental regulations [15]. The main advantage of adsorption process is that there is no sludge generation [16]. Specifically, activated carbon is a splendid adsorbent with good chemical properties, as well as large surface area, high porous nature, great number of active sites for adsorption, and strong adsorption capacity [17, 18]. On the other hand, commercially available activated carbons are highly expensive and hence recently activated carbon derived from agricultural wastes (due to existence of 
functional groups containing oxygen, e.g., carboxyl, carbonyl, hydroxyl and phenolic groups) is used for the expulsion of $\mathrm{Cr}(\mathrm{VI})$ such as Mangifera indica seed shell [19], wheat straw and Eupatorium adenophorum [20], Prosopis juliflora bark [21], rice straw [22], Longan seed [23], African biomass residues [24], sugarcane baggage [25], etc. The adsorption mechanisms are associated with surface complexation, chemisorptions, diffusion through micropores, electrostatic interactions and ion-exchange [26]. Thus, the potential use of Thuja occidentalis leaves carbon (TOLC) as an abundant, economical, renewable and useful material for the expulsion of $\mathrm{Cr}(\mathrm{VI})$ metal ions is altogether examined in this paper. If the carbon prepared from Thuja occidentalis leaves is confirmed to be successful in the expulsion of $\mathrm{Cr}(\mathrm{VI})$, it would give the industries a plentiful source of the inexpensive carbonbased adsorbent for the effective treatment method and remediation of $\mathrm{Cr}(\mathrm{VI})$ rich water. However, there is no published literature available on the use of TOLC for the expulsion of $\mathrm{Cr}(\mathrm{VI})$. The fundamental parameters considered are varying $\mathrm{pH}$, varying $\mathrm{Cr}(\mathrm{VI})$ initial concentration, time of contact period and TOLC dosage utilizing characteristic adsorbent by adsorption system with batch adsorption mode. Langmuir and Freundlich's models are considered to explain the equilibrium character of $\mathrm{Cr}(\mathrm{VI})$ adsorption onto the adsorbent material. The adsorption and ratelimiting step of the transport mechanism is also studied using kinetic models.

\section{Experimental}

\subsection{Plant Description}

Thuja occidentalis is also called as northern whitecedar or eastern arborvitae, and it is broadly utilized as an ornamental tree, especially, for screens and supports. The leaf and its leaf oil have been utilized for the treatments of respiratory tract diseases, bacterial skin contaminations and hair arrangements and so forth. The leaves of Thuja occidentalis [27] are collected from the local region of Srikakulam district, Andhra Pradesh, India as a forerunner for preparing activated carbon.

\subsection{Preparation of Thuja Occidentalis Leaves Carbon Adsorbent}

Thuja occidentalis leaves were washed with triple distilled water thoroughly to take away grime and dust particles on it. The washed leaves were put in sunlight for 4-5 days. The dried leaves were grinded to a fine powder. The fine powder was taken in a conical flask and concentrated sulphuric acid was added to the fine powder slowly under constant stirring with the ratio of $1: 1.8$ $(\mathrm{w} / \mathrm{w})$. The resultant product was heated at $433 \pm 5 \mathrm{~K}$ on a hot plate for $5 \mathrm{~h}$ [28-30]. After heating, the obtained material was washed with distilled water for few times until free from sulphuric acid. The material was dried out in the oven at $378 \pm 5 \mathrm{~K}$. Finally, the material (TOLC) was grinded to the required size of $<75 \mu \mathrm{m}$ and the material was stored in a plastic container for future use.

\subsection{Materials and Methods}

$1000 \mathrm{mg} / \mathrm{l}$ of standard $\mathrm{Cr}(\mathrm{VI})$ solution was prepared using potassium dichromate. The necessary operational concentrations of $\mathrm{Cr}(\mathrm{VI})$ can be made from $1000 \mathrm{mg} / 1$ solution by accurate dilution. $0.01 \mathrm{~N} \mathrm{H}_{2} \mathrm{SO}_{4}$ and $0.01 \mathrm{~N} \mathrm{NaOH}$ were used for $\mathrm{pH}$ adjustments. All chemicals were of analytical reagent (AR) grade. The surface area and porous volume of the TOLC were determined by quantachrome instrument (surface area analyzer Nova 3200), using nitrogen as adsorbate at $77 \mathrm{~K}$. The FTIR spectrum was measured within $4000-400 \mathrm{~cm}^{-1}$ using a single beam, Perkin Elmer BX FTIR; anhydrous potassium bromide was used as a pellet material. Scanning electron microscopic images were taken using Philips XL 30 microscope equipped with an energy dispersive X-ray analyzer to study the surface morphology of the CATLC and elemental composition analysis. The amount of $\mathrm{Cr}(\mathrm{VI})$ present in the solution was measured using UV-Vis double beam spectrophotometer (Systronics, AU 2701). Systronics digital $\mathrm{pH} / \mathrm{mv}$ meter, model 335 was used for the measurement of $\mathrm{pH}$. The TOLC characteristics were: surface area $798.4 \mathrm{~m}^{2} / \mathrm{g}$; pore volume $0.572 \mathrm{~cm}^{3} / \mathrm{g}$; particle size $<75 \mu \mathrm{m}$ and $\mathrm{pH}_{\mathrm{ZPC}} 6.54$.

\subsection{Batch Adsorption Studies}

The batch mode study was executed by taking predetermined concentrations $(80-150 \mathrm{mg} / \mathrm{l})$ of $50 \mathrm{ml}$ of $\mathrm{Cr}(\mathrm{VI})$ solution with predetermined amounts $(2.0-20 \mathrm{~g}$ per litre of $\mathrm{Cr}(\mathrm{VI})$ solution) of TOLC at predetermined $\mathrm{pH}$ values (2.5-9.0) in $250 \mathrm{ml}$ conical flasks and agitated using an orbital shaker (stirring rate $180 \mathrm{rpm}$ ) for 10 $80 \mathrm{~min}$. After agitation with successful time intervals, the solid residuals were separated using Whatman filter paper-41 with vacuum filtration pump, and the filtrate containing $\mathrm{Cr}(\mathrm{VI})$ was analyzed using UV-Visible double beam spectrophotometer (Systronics, Model AU 2701) to know the optimum condition of the time interval. The same procedure was carried out, when one parameter was varied and remaining parameters were kept fixed under knowing optimum conditions of $\mathrm{pH}$, TOLC dosage and $\mathrm{Cr}(\mathrm{VI})$ concentration. The entire process was conducted at room temperature. The percentage expulsion of $\mathrm{Cr}(\mathrm{VI}), R$, and quantity of $\mathrm{Cr}(\mathrm{VI})$ uptake, $Q_{e}$, can be determined by Eqs. (1) and (2). 


$$
\begin{aligned}
& R=\frac{C_{i}-C_{f}}{C_{0}} \cdot 100 \% \\
& Q_{e}=\frac{C_{i}-C_{f}}{m} \cdot V
\end{aligned}
$$

where $C_{i}$ and $C_{f}$ are initial and final concentration of $\mathrm{Cr}(\mathrm{VI})$, respectively, $\mathrm{mg} / \mathrm{l} ; m$ is the quantity of TOLC, $\mathrm{g}$; $V$ is the volume of $\mathrm{Cr}(\mathrm{VI})$ solution, 1 .

\section{Results and Discussion}

\subsection{Adsorption Studies for the Expulsion of $\mathrm{Cr}(\mathrm{VI})$}

\subsubsection{Influence of TOLC dosage}

It is important to fix the dosage of TOLC to plan the optimum treatment systems for fast response of the examination. To achieve this, a series of batch mode experiments were performed with the TOLC dose of 2.0 to $20.0 \mathrm{~g}$ per litre of the working solution $(100 \mathrm{mg} / \mathrm{l}$ $\mathrm{Cr}(\mathrm{VI})$ solution) at the predetermined $\mathrm{pH} 3.00$ and the period of $70 \mathrm{~min}$. It is noticed that the $\mathrm{Cr}(\mathrm{VI})$ expulsion efficiency increases by increasing the TOLC dosage from 2.0 to $16.0 \mathrm{~g}$. A maximum percentage expulsion of $95.7 \%$ (Fig. 1a) is obtained at $16.0 \mathrm{~g}$ of TOLC per litre of $\mathrm{Cr}(\mathrm{VI})$ solution. When the adsorbent dosage increases, there is an enhancement of the active binding sites number [31] available on the surface of TOLC adsorbent, and hence the expulsion of $\mathrm{Cr}(\mathrm{VI})$ increases. But an additional increment in the amount of TOLC dosage does not have any considerable increment in the expulsion of $\mathrm{Cr}(\mathrm{VI})$ ion due to the existence of an equilibrium between adsorbate and TOLC adsorbent. However, the $\mathrm{Cr}(\mathrm{VI})$ uptake $\left(Q_{e}\right)$ on the adsorbent surface decreases from 18.95 to $4.785 \mathrm{mg} / \mathrm{g}$ of $\mathrm{Cr}(\mathrm{VI})$ on the adsorbent surface when the adsorbent dosage increases from 2 to $20 \mathrm{~g} / \mathrm{l}$ of $\mathrm{Cr}(\mathrm{VI})$ solution, as shown in Fig. 1a, since the number of $\mathrm{Cr}(\mathrm{VI})$ ions are fixed to adsorb on the surface. Based on this observation, the adsorbent dosage of $16 \mathrm{~g} / \mathrm{L}$ of $\mathrm{Cr}(\mathrm{VI})$ solution was taken as fixed for further studies.

\subsubsection{Influence of initial pH}

Adsorption is mainly controlled by $\mathrm{pH}$ which influences the speciation of metals through redox reactions, hydrolysis and complexation during metal recuperation. There is a favourable $\mathrm{pH}$ range for the maximum adsorption of each metal on an adsorbent surface [32]. The $\mathrm{pH}$ reliance of $\mathrm{Cr}(\mathrm{VI})$ adsorption mainly is associated with the ionic state and type of different functional groups on the TOLC as well as $\mathrm{Cr}(\mathrm{VI})$ speciation in aqueous solution. The $\mathrm{pH}$ value needed to confer zero point charge was determined for TOLC [33].
A graph drawn between final $\mathrm{pH}$ versus initial $\mathrm{pH}$ gives a curve, from where the $\mathrm{pH}_{\mathrm{zpc}}$ for TOLC was identified as the point, at which the change of $\mathrm{pH}$ is zero. The experimental results show that $\mathrm{pH}_{\mathrm{zpc}}$ (zero point charge) of TOLC is obtained as 6.54. This indicates that TOLC adsorbent surface is positively charged below 6.54 and negatively charged above $6.54[34,35]$. The experiments are performed by altering the $\mathrm{pH}$ from 2.5 to 9.0 per $50 \mathrm{ml}$ of the working solution $(100 \mathrm{mg} / \mathrm{l}$ of $\mathrm{Cr}(\mathrm{VI})$ solution) at the predetermined dosage of $16 \mathrm{~g}$ per litre of $\mathrm{Cr}(\mathrm{VI})$ solution and the period of $70 \mathrm{~min}$. Chromium shows various kinds of $\mathrm{pH}$-dependent equilibriums in aqueous solution. As the solution $\mathrm{pH}$ changes, there is a shift in the equilibriums. $\mathrm{Cr}_{2} \mathrm{O}_{7}{ }^{2-}$ and $\mathrm{HCrO}_{4}^{-}$species are in equilibrium at $\mathrm{pH}$ of $2.0-6.0, \mathrm{Cr}_{4} \mathrm{O}_{13}{ }^{2-}$ and $\mathrm{Cr}_{3} \mathrm{O}_{10}{ }^{2-}$ are present at lower $\mathrm{pH}$ values. At lower $\mathrm{pH}$ values a strong electrostatic attraction exits between positively charged adsorbent surfaces and chromate anions. Lower adsorption of chromium that takes place at $\mathrm{pH} \geq 6$ might be owing to competition between two anions $\left(\mathrm{OH}^{-}\right.$and $\left.\mathrm{CrO}_{4}{ }^{2-}\right)$ on the adsorbent surface [36]. In this investigation, the adsorption rate was enhanced from 93.1 to $95.7 \%$ by increasing $\mathrm{pH}$ from 2.5 to 3.0 . As the $\mathrm{pH}$ value is increased, the adsorption competence quickly reduced. The percentage expulsion of $\mathrm{Cr}(\mathrm{VI})$ is greater than $80 \%$ when $\mathrm{pH}$ ranges from 3.0 to 4.0 , however, the highest percentage of removal is obtained at $\mathrm{pH}$ of 3.0. Overall, as $\mathrm{pH}$ is varying from 3.0 to 9.0 , the $\mathrm{Cr}(\mathrm{VI})$ expulsion decreases from 95.7 to $42.7 \%$. The possible explanation for higher adsorption in an acidic medium is that the $\mathrm{Cr}(\mathrm{VI})$ is oxidized to $\mathrm{Cr}(\mathrm{III})$ state[37]. A maximum percentage expulsion of $95.7 \%$ (Fig. 1b) is obtained at $\mathrm{pH}$ of 3.0 and is considered for further studies. The $\mathrm{Cr}(\mathrm{VI})$ uptake $Q_{e}$ on the TOLC surface decreases from 5.981 to $2.668 \mathrm{mg} / \mathrm{g}$ of $\mathrm{Cr}(\mathrm{V})$ on the adsorbent surface as the $\mathrm{pH}$ increases from 3.0 to 9.0.

\subsubsection{Influence of initial $\mathrm{Cr}(\mathrm{VI})$ concentration}

$\mathrm{Cr}(\mathrm{VI})$ solutions with different concentrations of $80-150 \mathrm{mg} / \mathrm{l}$ at optimum $\mathrm{pH}$ of 3.0 were equilibrated utilizing optimum dosage of $16 \mathrm{~g}$ per lire of $\mathrm{Cr}(\mathrm{VI})$ solution. Fig. 1c demonstrates that the $\mathrm{Cr}(\mathrm{VI})$ uptake on the TOLC adsorbent surface enhanced from 4.918 to $6.55 \mathrm{mg} / \mathrm{g}$ and expulsion efficiency reduced from 98.3 to $69.8 \%$ when the concentration was varied from 80 to $150 \mathrm{mg} / \mathrm{l}$. The increasing $\mathrm{Cr}(\mathrm{VI})$ uptake on TOLC surface by increasing initial concentration is due to more $\mathrm{Cr}(\mathrm{VI})$ ions being accessible in the solution, and hence more adsorption takes place because of the improvement in contact [38].The expulsion of $\mathrm{Cr}(\mathrm{VI})$ is decreased by increasing the initial concentration of $\mathrm{Cr}(\mathrm{VI})$, which is mostly due to the active sites being saturated and exchange sites getting almost filled. This trend represents that very small number of sites are involved in the adsorption by increasing $\mathrm{Cr}(\mathrm{VI})$ concentration. 


\subsubsection{Influence of contact time}

$\mathrm{Cr}(\mathrm{VI})$ solutions of concentration $100 \mathrm{mg} / \mathrm{l}$ with various time intervals from 10 to 80 min at optimum $\mathrm{pH}$ value of 3.0 were equilibrated utilizing the optimum dosage of $16.0 \mathrm{~g}$. The impact of the contact period between the TOLC adsorbent with $\mathrm{Cr}(\mathrm{VI})$ solution on the adsorption capability of TOLC and $\mathrm{Cr}(\mathrm{VI})$ uptake on the TOLC surface is represented in Fig. 1d. There is a sharp increment in the adsorption with the increase in the contact period of up to about $70 \mathrm{~min}$ and then it tends to settle at a consistent value, since initially more number of active sites were present on the TOLC adsorbent surface. Thus, adsorption takes place more rapidly, whereas desorption takes place at a lower rate. Therefore, the net impact is a greater increment in the degree of adsorption. When the active sites get filled, the rates of adsorption, as well as desorption, have a tendency to be equivalent and degree of adsorption decreases and inevitably turns out to be about consistent at equilibrium [39].

\subsection{Adsorption Isotherm Studies}

The adsorption isotherms usually specify how the masses of required ions are dispersed among the solid and

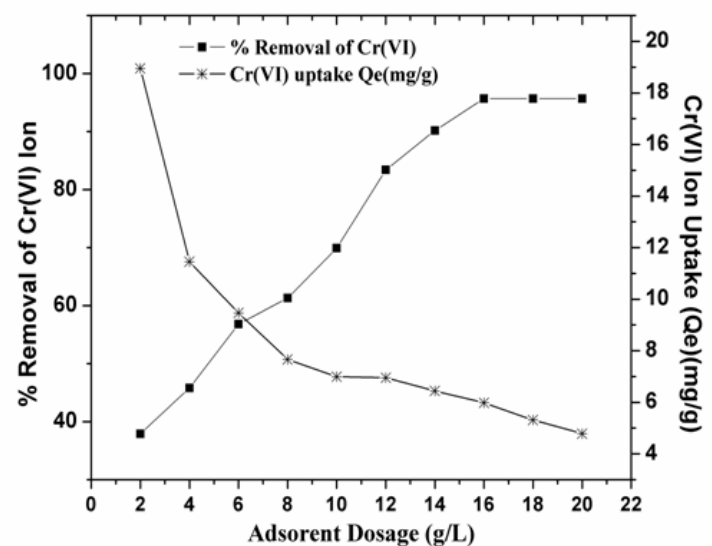

a)

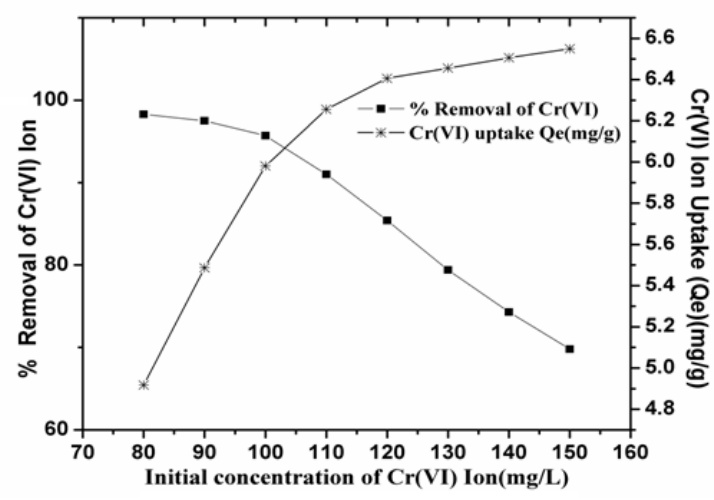

c) liquid phases at equilibrium condition. Also, it corresponds to the relation between the extent of $\mathrm{Cr}(\mathrm{VI})$ adsorbed per unit mass of the TOLC under equilibrium condition at a constant temperature. Here, Langmuir [40] and Freundlich [41] isotherm models are considered to identify the adsorption capacity for $\mathrm{Cr}(\mathrm{VI})$ removal using TOLC.

The Langmuir isotherm is represented by Eq. (3):

$$
\frac{1}{Q_{e}}=\frac{1}{Q_{m} b C_{e}}+\frac{1}{Q_{m}}
$$

where $Q_{e}$ is the mass of $\mathrm{Cr}(\mathrm{VI})$ uptake, $\mathrm{mg} / \mathrm{g} ; Q_{m}$ is the maximum adsorption capability of TOLC, $\mathrm{mg} / \mathrm{g} ; C_{e}$ is the equilibrium concentration, $\mathrm{mg} / \mathrm{l} ; b$ is a constant indicating the energy of adsorption.

The Freundlich isotherm is represented by Eq. (4):

$$
\ln Q_{e}=\ln K_{f}+\frac{1}{n_{f}} \ln C_{e}
$$

where $Q_{e}$ is the mass of $\mathrm{Cr}(\mathrm{VI})$ uptake, $\mathrm{mg} / \mathrm{g} ; C_{e}$ is the equilibrium concentration, $\mathrm{mg} / \mathrm{l} ; K_{f}$ is associated with adsorption capability and $1 / n_{f}$ is the quantity of adsorption intensity.

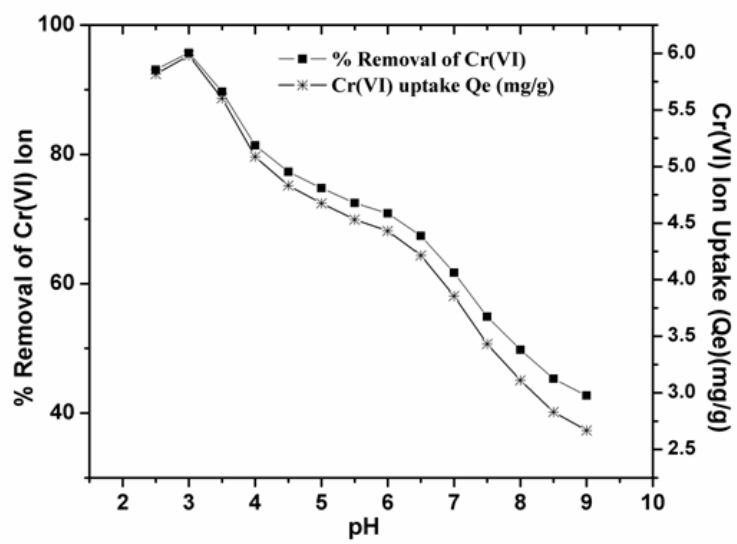

b)

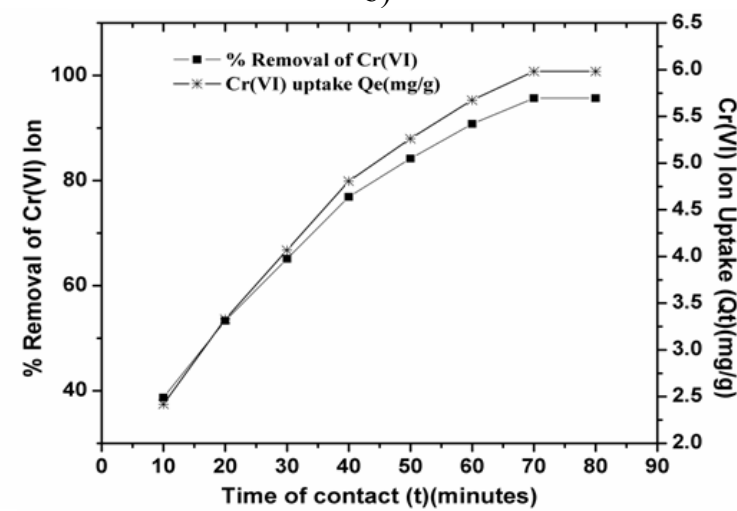

d)

Fig. 1. Impact of various parameters on percentage expulsion of $\mathrm{Cr}(\mathrm{VI})$ and $\mathrm{Cr}(\mathrm{VI})$ ions uptake (mg/gm) using TOLC: TOLC dosage (a); solution $\mathrm{pH}(\mathrm{b})$, initial concentration of $\mathrm{Cr}(\mathrm{VI})$ (c) and time of contact (d) 
The Langmuir and Freundlich adsorption isotherm constants are measured from the graphs of $1 / Q_{e} v s .1 / C_{e}$ and $\ln C_{e}$ vs. $\ln Q_{e}$ (Fig. 2). The obtained values are represented in Table 1. The obtained correlation coefficient value $R^{2}$ for Langmuir is 0.999 and for Freundlich -0.8776 . It represents that Langmuir isotherm is a better fit than Freundlich model and also represents that $\mathrm{Cr}(\mathrm{VI})$ uptake takes place on the homogenous surface of adsorbent by unilayered adsorption [42].
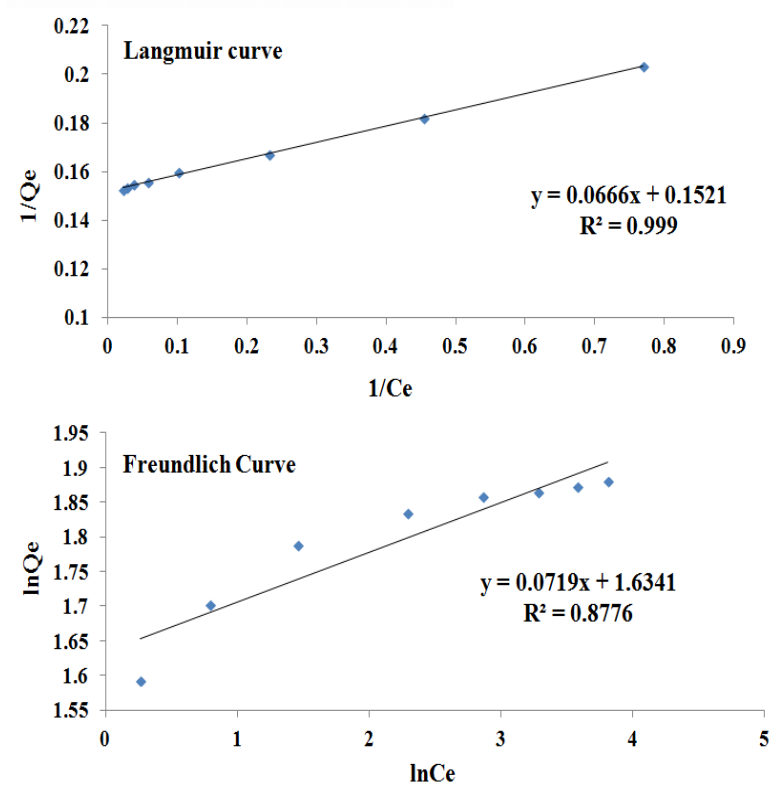

Fig. 2. Langmuir and Freundlich trendline curves using TOLC (particle size $<75 \mu \mathrm{m}$ )
The important characteristic of Langmuir may also be indicated regarding dimensionless equilibrium separation factor $R_{L}$ and is measured by Eq. (5).

$$
R_{L}=\frac{1}{1+b C_{i}}
$$

where $C_{i}$ is the initial $\mathrm{Cr}(\mathrm{VI})$ concentration, $\mathrm{mg} / \mathrm{l}$ and $b$ can be determined by Langmuir plot.

The $R_{L}$ value represents the adsorption process either favorable $\left(0<R_{L}<1\right)$, unfavourable $\left(R_{L}>1\right)$ or irreversible $\left(R_{L}=0\right)$ [43]. The obtained $R_{L}$ value is 0.0419 , which shows that adsorption process is favourable using TOLC for the $\mathrm{Cr}(\mathrm{VI})$ removal.

\subsection{Kinetic Studies}

Adsorption kinetics examination gives a comprehension of adsorption rate and controlling mechanism of the procedure. With a specific end goal to clarify the adsorption energy of $\mathrm{Cr}(\mathrm{VI})$ by TOLC adsorbent, four kinetic adsorption isotherm models, for example, pseudofirst order, pseudo-second order, intra-particle diffusion, and Elovich [44] were studied.

The lineralized type of the four models and calculated kinetic parameters are represented in Table 2. The respective kinetic adsorption graphs are shown in Fig. 3 . It is observed that the regression constant proximity to the value of $R^{2}=0.9927$ represents that the pseudosecond-order isotherm is a better fit. Hence, the chemisorptions are the rate-limiting step for the adsorption of $\mathrm{Cr}(\mathrm{VI})$ [45].

Table 1

Values of adsorption isotherm constants

\begin{tabular}{|c|c|c|c|c|c|}
\hline $\begin{array}{c}\text { Adsorption } \\
\text { isotherm models }\end{array}$ & Linear form & Graph & $R^{2}$ & Parameters & $\begin{array}{c}\text { Obtained } \\
\text { value }\end{array}$ \\
\hline Langmuir Model & $\frac{1}{Q_{e}}=\frac{1}{Q_{m} b C_{e}}+\frac{1}{Q_{m}}$ & $1 / C_{e} v s .1 / Q_{e}$ & 0.999 & $b$ & 0.2283 \\
\hline $\begin{array}{c}\text { Freundlich } \\
\text { Model }\end{array}$ & $\ln Q_{e}=\ln K_{f}+\frac{1}{n_{f}} \ln C_{e}$ & $1 \ln C_{e} v s . \ln Q_{e}$ & 0.8776 & $R_{L}$ & 0.0419 \\
\cline { 2 - 6 } & & & $1 / n_{f}$ & 0.0719 \\
\hline
\end{tabular}

Table 2

Values of kinetic adsorption constants

\begin{tabular}{|c|c|c|c|c|c|}
\hline Kinetic model & Linear expression & Graph & $R^{2}$ & Constants & $Q_{e}$ \\
\hline $\begin{array}{c}\text { Pseudo-first } \\
\text { order kinetic }\end{array}$ & $\ln \left(Q_{e}-Q_{t}\right)=\ln Q_{e}-K_{1} t$ & $\ln \left(Q_{e}-Q_{t}\right)$ vs. $t$ & 0.9626 & $K_{1}=-0.047$ & 6.841 \\
\hline $\begin{array}{c}\text { Pseudo-second } \\
\text { order kinetic }\end{array}$ & $t / Q_{t}=1 / k_{2} Q_{e}^{2}+1 / Q_{e} t$ & $t / Q_{t}$ vs. $t$ & 0.9927 & $K_{2}=0.0046$ & 8.07 \\
\hline $\begin{array}{c}\text { Intra particle } \\
\text { diffusion }\end{array}$ & $Q_{t}=K_{i} t^{0.5}$ & $Q_{t}$ vs. $t^{0.5}$ & 0.970 & $K_{i}=0.722$ & - \\
\hline Elovich & $Q_{t}=\frac{1}{\beta} \ln (\alpha \beta)+\frac{1}{\beta} \ln t$ & $Q_{t} v s . \ln t$ & 0.9869 & $\begin{array}{c}\alpha=0.621 \\
\beta=0.539\end{array}$ & - \\
\hline
\end{tabular}

Notes: $Q_{e}$ and $Q_{t}$ are the $\mathrm{Cr}(\mathrm{VI})$ uptake at equilibrium and time $t(\mathrm{~min})$, respectively, $\mathrm{mg} / \mathrm{g} ; k_{1}$ is the pseudo-first-order rate constant, $\min ^{-1} ; k_{2}$ is the pseudo-second-order rate constant, $\mathrm{g} \cdot(\mathrm{mg} / \mathrm{min})^{-1} ; k_{i}$ is the intraparticle diffusion rate constant, $\mathrm{mg} \cdot\left(\mathrm{g} \cdot \mathrm{min}^{0.5}\right)^{-1}$. Initial adsorption rate is represented as $\alpha, \mathrm{mg} \cdot(\mathrm{g} \cdot \mathrm{min})$ and $\beta$ is the surface coverage, $\mathrm{g} / \mathrm{mg}$, as well as activation energy for chemisorptions. 

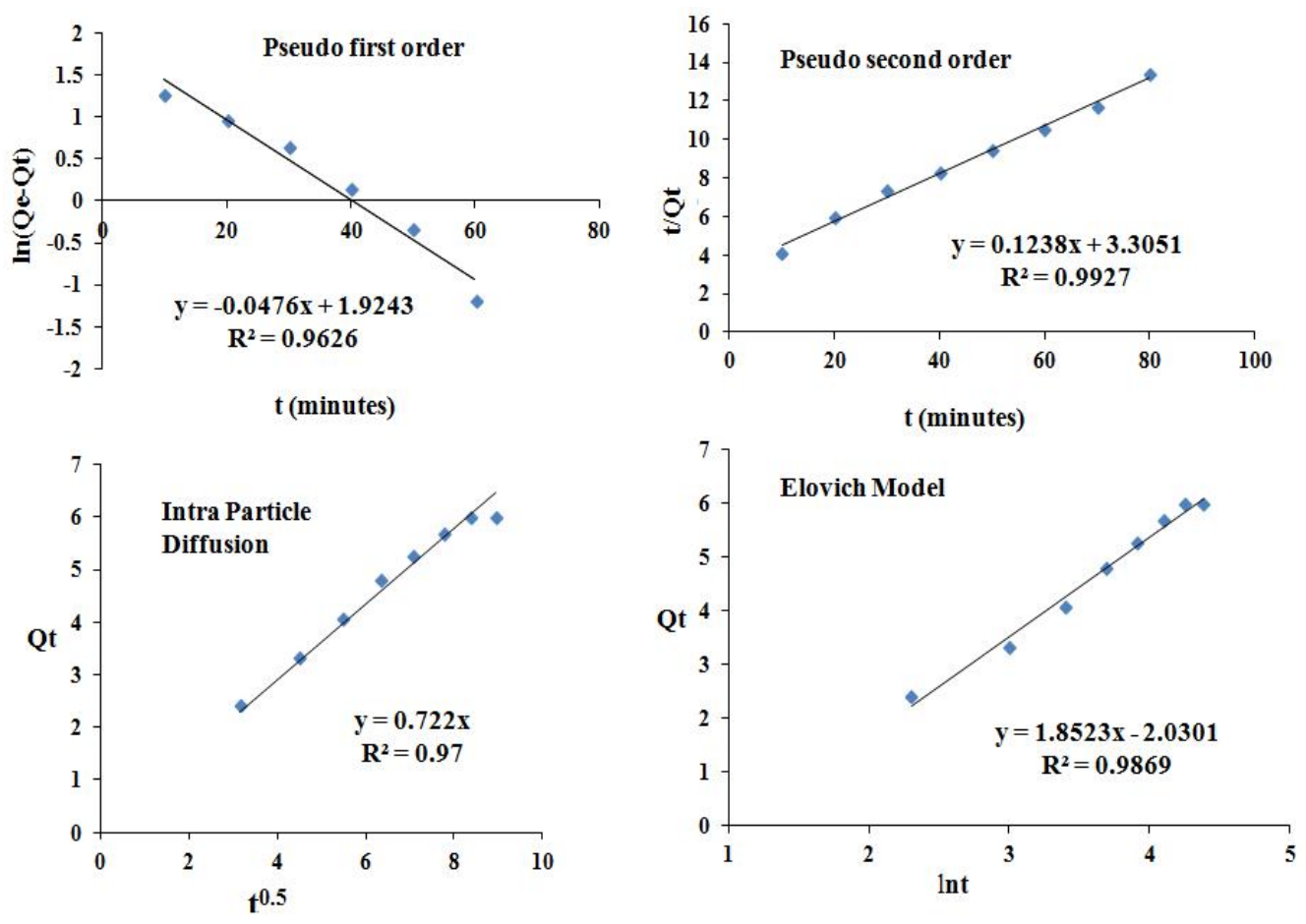

Fig. 3. Kinetic adsorption isotherm graphs: the pseudo-first order model, the pseudo-second-order model, the intra-particle diffusion model, and the Elovich model

\subsection{Characterization Studies of TOLC}

\subsubsection{FTIR study}

FTIR spectra are recorded for examining the presence of various functional groups in the TOLC adsorbent. FTIR spectra of TOLC material before $\mathrm{Cr}(\mathrm{VI})$ and after $\mathrm{Cr}(\mathrm{VI})$ adsorption are shown in Fig. 4 and the corresponding FTIR data are presented in Table 3. The spectra of TOLC before adsorption shows a vibrational peak at $3374 \mathrm{~cm}^{-1}$ correspond to $-\mathrm{OH}$ stretching value in hydroxyl groups. It is shifted to $3389 \mathrm{~cm}^{-1}$ after $\mathrm{Cr}(\mathrm{VI})$ was adsorbed. The peak at $3071 \mathrm{~cm}^{-1}$ before adsorption represents the hydroxyl stretching band in the carboxylic group and is shifted to $2995 \mathrm{~cm}^{-1}$ after $\mathrm{Cr}(\mathrm{VI})$ adsorption. The stretching vibration peak at $1707 \mathrm{~cm}^{-1}$ indicates the $\mathrm{C}=\mathrm{O}$ group in carboxylic acid and is shifted to $1712 \mathrm{~cm}^{-1}$. The carboxylic groups are typically apparent to partake in the heavy metal adsorption [46]. These groups most probably act as proton donors and undergo deprotonation. The peak at $2879 \mathrm{~cm}^{-1}$ corresponds to the presence of $-\mathrm{CH}-$ or $-\mathrm{CH}_{2}-$ on the TOLC surface and is shifted to $2924 \mathrm{~cm}^{-1}$. The peak at $1596 \mathrm{~cm}^{-1}$ corresponds to the stretching vibration band of $\mathrm{C}=\mathrm{C}$ in aromatic groups. The peaks at 1171 and $1030 \mathrm{~cm}^{-1}$ represent the existence of $-\mathrm{C}-\mathrm{O}$ in alcoholic, carboxylic or phenolic functionalities on the TOLC surface and are shifted to 1237 and $1044 \mathrm{~cm}^{-1}$ respectively. The peak at $625 \mathrm{~cm}^{-1}$ indicates the
C-S stretching band on the TOLC surface and is shifted to $630 \mathrm{~cm}^{-1}$. There is also a shift in the vibrational bands occurring mainly due to adsorption of $\mathrm{Cr}(\mathrm{VI})$ by TOLC adsorbent since the existence of polar functional groups on the TOLC surface probably provides significant ion exchange to the TOLC adsorbent [47]. The EDX spectra reveal the presence of chromium on the adsorbent surface after adsorption treatment. Also, no band vanishing is seen during the procedure of adsorption showing that TOLC is a magnificent inexhaustible adsorbent for treatment of wastewater.

\subsubsection{SEM study}

The SEM images (Fig. 5) illustrates morphology of the TOLC adsorbent before (a, b) and after (c, d) $\mathrm{Cr}(\mathrm{VI})$ adsorption on TOLC at different magnifications. The TOLC raw powder surface before $\mathrm{Cr}(\mathrm{VI})$ adsorption has particles with the small size of 74-214 nm, and also some larger particles are observed with non-regular shape. The micro- and macroporous nature of certain regions in the particles are observed, which provides sufficient active sites for adsorption [48]. The surface of the TOLC powder after $\mathrm{Cr}(\mathrm{VI})$ adsorption have particles with the sizes ranging from 74 to $214 \mathrm{~nm}$ and more. Partial porous regions in the TOLC are observed, perhaps due to the decreased porosity and being simultaneously covered by the adsorbed $\mathrm{Cr}(\mathrm{VI})$ ions on the surface. This is apparent for the $\mathrm{Cr}(\mathrm{VI})$ adsorption on the TOLC surface. 

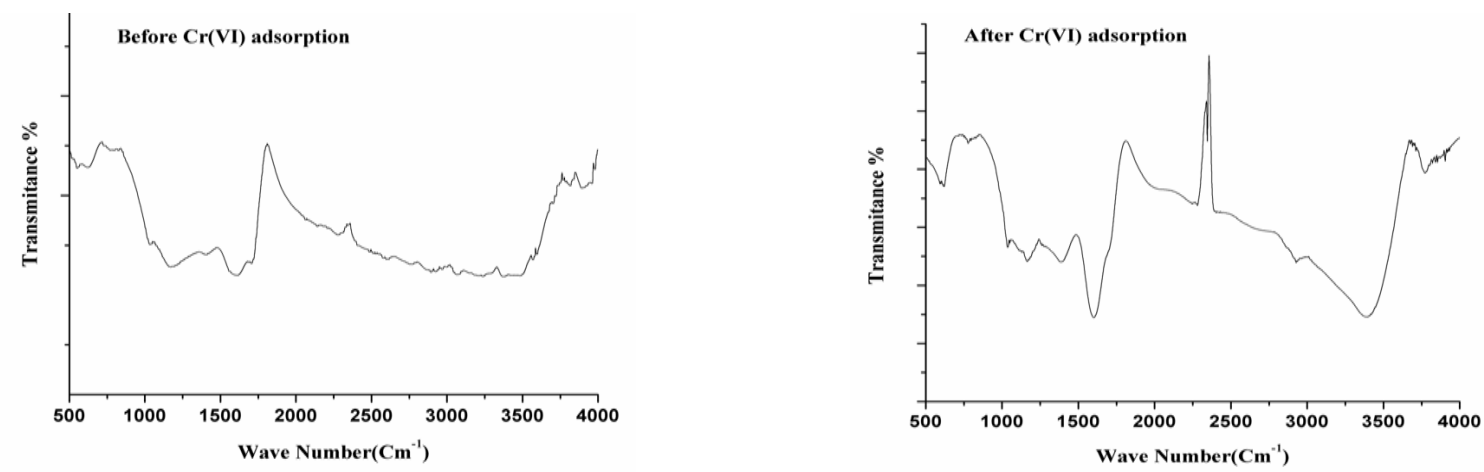

Fig. 4. FTIR spectra of TOLC before and after Cr(VI) adsorption

Table 3

FTIR data of TOLC before and after $\mathrm{Cr}(\mathrm{VI})$ adsorption

\begin{tabular}{|c|c|c|}
\hline $\begin{array}{c}\text { TOLC (before Cr(VI) } \\
\text { adsorption) }\end{array}$ & $\begin{array}{c}\text { TOLC (after Cr(VI) } \\
\text { adsorption }\end{array}$ & Bond stretching values \\
\hline 3566 & 3682 & Phenolic - OH stretching band \\
\hline 3374 & 3389 & Hydroxyl - OH stretching band \\
\hline 3071 & 2995 & Carboxylic acid - OH stretching band \\
\hline 2879 & 2924 & $\mathrm{CH}-\mathrm{C}=\mathrm{C}$ stretching in $\mathrm{CO}_{2}$ antisymmetric stretching vibration \\
\hline 2354 & 2277 & $\mathrm{C}=\mathrm{O}$ stretching in carboxylic acid \\
\hline 1707 & 1712 & $\mathrm{C}=\mathrm{C}$ in aromatic \\
\hline 1596 & 1600 & $-\mathrm{C}-\mathrm{H}$ bending vibration \\
\hline 1414 & 1388 & $\mathrm{C}-\mathrm{O}$ stretching in hydroxyl, acids or phenolic \\
\hline 1171,1030 & 1237,1044 & Aromatic $-\mathrm{C}-\mathrm{H}$ bending vibration \\
\hline 777 & 782 & $\mathrm{C}-\mathrm{S}$ stretching band \\
\hline 625 & 630 &
\end{tabular}
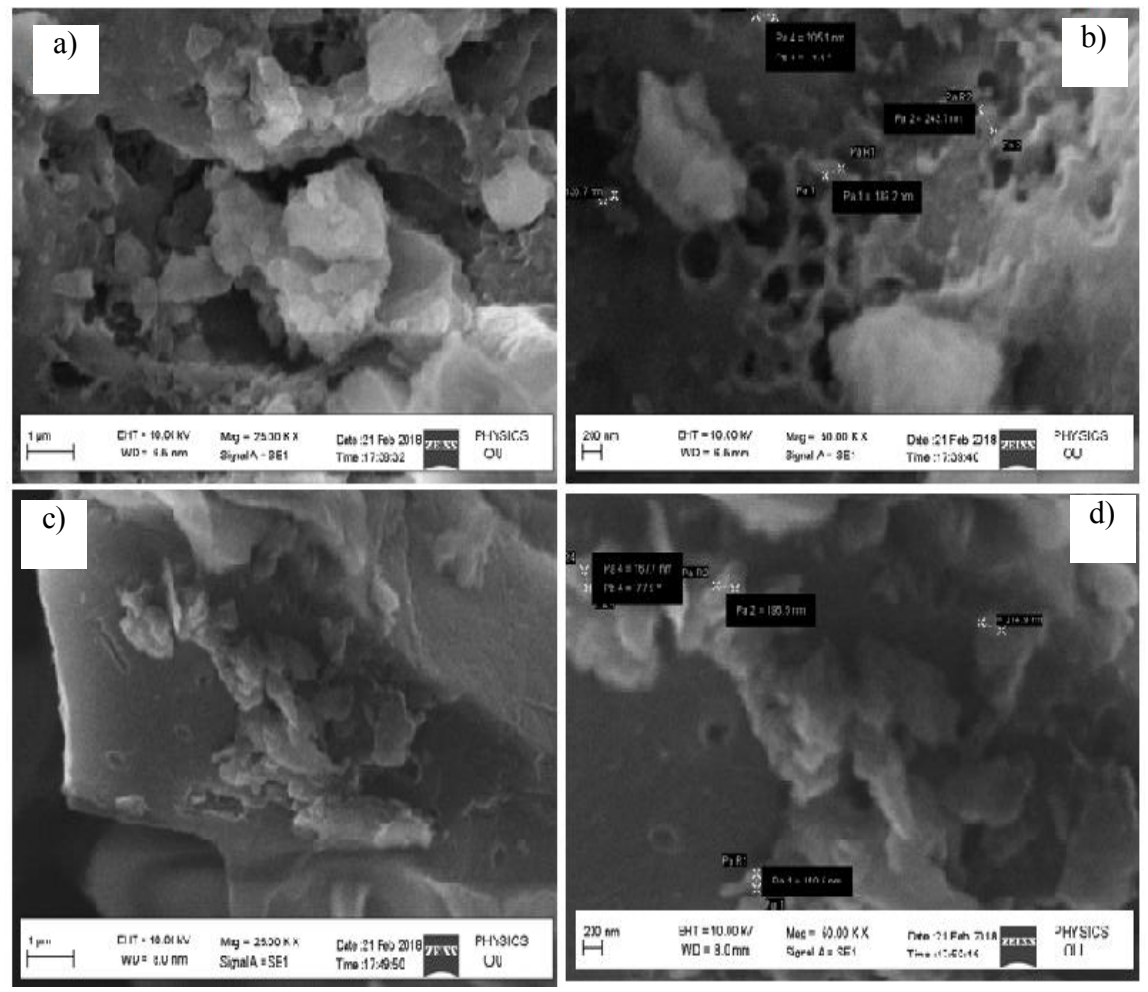

Fig. 5. SEM image of TOLC before(a, b) and after (c, d) Cr(VI) adsorption 


\subsubsection{EDX study}

The EDX spectra and elemental composition of an adsorbent give the information about the composition changes of the elements on the TOLC surface before and after $\mathrm{Cr}(\mathrm{VI})$ adsorption. EDX spectra portray the presence of elements like carbon, oxygen and sulphur of raw powder TOLC before adsorption and presence of elements like carbon, oxygen, sulphur, and chromium of TOLC after adsorption. The Cr(VI) adsorption is affirmed by the EDX investigation, which is demonstrated by the appearance of the peak of $\mathrm{Cr}(\mathrm{VI})$ in the EDX of TOLC after $\mathrm{Cr}(\mathrm{VI})$ adsorption. The peak of $\mathrm{Cr}(\mathrm{VI})$ was not seen on the surface of TOLC before $\mathrm{Cr}(\mathrm{VI})$ adsorption as shown in Fig. 6. Also, it can be observed that TOLC has higher carbon and oxygen content and these are major components in TOLC adsorbent. Hence, hydroxyl and carboxyl groups are possible functional groups for the $\mathrm{Cr}(\mathrm{VI})$ adsorption. The presence of these groups was proved by the FTIR spectral data [49] earlier. Based on the above discussion, TOLC can permit the development of sufficient sites and required functional groups for complexation and chelation with $\mathrm{Cr}(\mathrm{VI})$ ions.

\subsection{Possible Mechanism for the Expulsion of $\mathrm{Cr}(\mathrm{VI})$ Using TOLC Adsorbent}

The polar functional groups, for example, carboxylic acid, hydroxyl groups and aromatic hydroxy groups there on the surface of the TOLC adsorbent can participate in chemical bonding, and these are accountable for the ion exchange capacity of the TOLC; additionally, there is an electrostatic attraction between the positively charged adsorbent with negatively charged chromate ion. So, the TOLC/Cr(VI) reaction might be indicated in two possible ways as represented in Fig. 7.

\subsection{Regeneration}

Recovering and reusability of the adsorbent would diminish handling costs and is imperative for industrial applications. The reusability of TOLC is tried by performing consecutive adsorption and desorption cycles with a regenerating agent of $0.01 \mathrm{~N} \mathrm{H}_{2} \mathrm{SO}_{4}$. The recovered TOLC adsorbent is utilized for the expulsion of $\mathrm{Cr}(\mathrm{VI})$ with the same $100 \mathrm{mg} / \mathrm{l}$ of $\mathrm{Cr}(\mathrm{VI})$ concentration. Desorption of $\mathrm{Cr}(\mathrm{VI})$ studies were carried out with $1 \mathrm{~g} / \mathrm{l}$ of $\mathrm{Cr}(\mathrm{VI})$ adsorbed utilizing $100 \mathrm{ml}$ of $0.01 \mathrm{~N} \quad \mathrm{H}_{2} \mathrm{SO}_{4}$ solution. The \% expulsion of $\mathrm{Cr}(\mathrm{VI})$ using regenerated TOLC is $86.2 \%$ for the first cycle, $81.4 \%$ for the second cycle and $78.1 \%$ for the third cycle. After the $3^{\text {rd }}-4^{\text {th }}$ cycles, the measures of adsorption and desorption had superb execution, demonstrating that TOLC could be a monetarily plausible technique for the expulsion of $\mathrm{Cr}(\mathrm{VI})$.

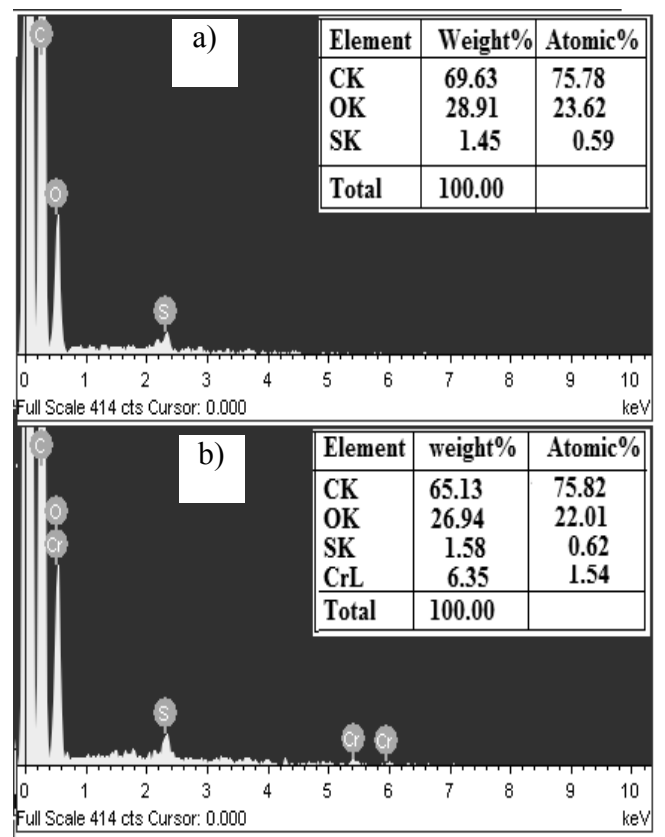

Fig. 6. EDX spectra along with elemental composition of TOLC before (a) and after (b) $\mathrm{Cr}(\mathrm{VI})$ adsorption

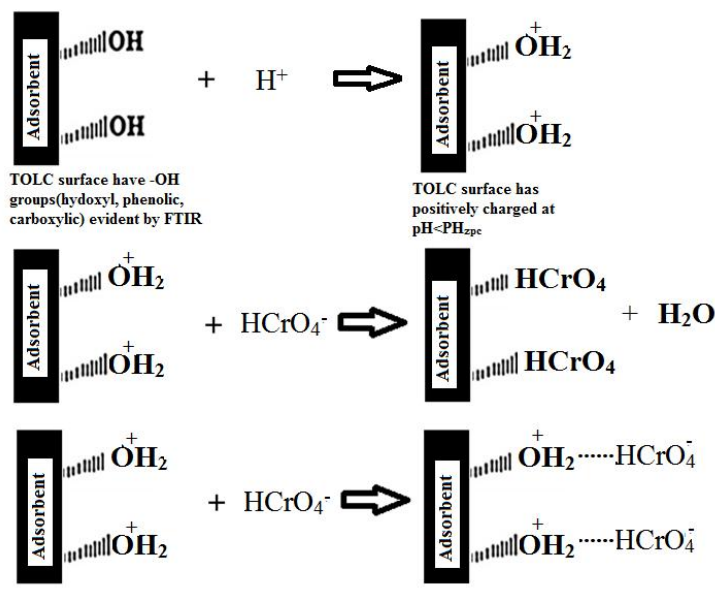

Fig. 7. Possible mechanism for the expulsion ofCr(VI) using TOLC adsorbent

\subsection{Comparative Studies of TOLC and Other Available Adsorbents}

A relative report has been considered for adsorption capacity of various adsorbent materials and the present adsorbent TOLC. The immediate connection of TOLC with various adsorbents is not simple because of various working conditions. An exertion is made (Table 4) for examination with some detailed adsorbents, and in perspective of the acquired results, the adsorption capability of TOLC for $\mathrm{Cr}(\mathrm{VI})$ is surprisingly more significant than other available low-cost adsorbents. 


\section{Comparison of TOLC with other existing adsorbents for the expulsion of $\mathrm{Cr}(\mathrm{VI})$}

\begin{tabular}{|l|c|c|c|}
\hline \multicolumn{1}{|c|}{ Adsorbent } & $\begin{array}{c}\mathrm{pH} \text { of the } \\
\text { solution }\end{array}$ & $\begin{array}{c}\text { Maximum adsorption } \\
\text { capability, mg/g }\end{array}$ & References \\
\hline Coconut tree sawdust activated carbon & 3.0 & 3.46 & {$[50]$} \\
\hline Bael fruit shell activated carbon & 2.0 & 17.27 & {$[51]$} \\
\hline Maize corn cob & 2.0 & 0.28 & {$[52]$} \\
\hline Sugarcane bagasse & 2.0 & 1.76 & {$[53]$} \\
\hline Cactus & 2.0 & 7.08 & {$[54]$} \\
\hline Swietenia mahagoni fruit shell & 3.0 & 2.3 & {$[55]$} \\
\hline TOLC & 3.0 & 5.981 & present work \\
\hline
\end{tabular}

\section{Conclusions}

TOLC turned out to be an extremely capable and exceedingly effective adsorbent of $\mathrm{Cr}(\mathrm{VI})$ adsorption in aqueous solutions. $\mathrm{Cr}(\mathrm{VI})$ adsorption is impacted by different parameters, for example, the initial dosage of TOLC, initial solution $\mathrm{pH}, \mathrm{Cr}(\mathrm{VI})$ concentration, and period of TOLC contact. The maximum expulsion of $\mathrm{Cr}(\mathrm{VI})$ has taken place at $\mathrm{pH}$ of 3.0. The working $\mathrm{pH}<\mathrm{pH}_{\mathrm{zpc}}$ of TOLC indicates that the surface of adsorbent is positively charged at $\mathrm{pH}$ of 3.0. FTIR and SEM studies confirmed the presence of various polar groups on the TOLC surface and porous nature. EDX gives evidence of the existence of chromium peak after adsorption of chromium using TOLC. The Langmuir and Freundlich isotherm models were utilised to clarify the adsorbate expulsion. The equilibrium adsorption of $\mathrm{Cr}(\mathrm{VI})$ over the whole concentration range was best depicted by the Langmuir isotherm, as shown by the high value of $R^{2}$ equal to 0.999 . The kinetic study indicates that the pseudo-second order $\left(R^{2}=0.9927\right)$ is the best fit and chemisorption is the rate-limiting step for the $\mathrm{Cr}(\mathrm{VI})$ adsorption on to the TOLC adsorbent. Finally, $\mathrm{Cr}(\mathrm{VI})$ can be desorbed by $0.01 \mathrm{~N} \mathrm{H}_{2} \mathrm{SO}_{4}$ solution and ultimately regenerated and recovered for several cycles. Hence, using TOLC for the expulsion of $\mathrm{Cr}(\mathrm{VI})$ is viewed as a supportable, financially affordable and effortlessly executed wastewater treatment innovation, as it does not require expensive pre-treatments.

\section{References}

[1] Djebbar M., Djafri F.: Chem. Chem. Technol., 2018, 12, 272. https://doi.org/10.23939/chcht12.02.272

[2] Mehdipour S., Vatanpour V., Kariminia H.: Desalination, 2015, 362, 84. https://doi.org/10.1016/j.desal.2015.01.030

[3] Skiba E., Kobyłecka J., Wolf W.: Environ. Pollut., 2017, 220B, 882. https://doi.org/10.1016/j.envpol.2016.10.072

[4] Wu L., Liao L., Lv G. et al.: J. Hazard. Mater., 2013, 254, 277. https://doi.org/10.1016/j.jhazmat.2013.03.009

[5] Lv X., Xu J., Jiang G. et al.: J. Colloid Interface Sci., 2012, 369, 460. https://doi.org/10.1016/j.jcis.2011.11.049
[6] Cheng Q., Wang C., Doudrick K., Chan C.: Appl. Catal. B, 2015, 176177, 740. https://doi.org/10.1016/j.apcatb.2015.04.047

[7] Sharma D., Forster C.: Bioresour. Technol., 1995, 52, 261.

https://doi.org/10.1016/0960-8524(95)00035-D

[8] Focardi S., Pepi M., Focardi S.: Microbial Reduction of Hexavalent Chromium as a Mechanism of Detoxification and Possible Bioremediation Applications. [in:] R. Chamy (Ed.), Biodegradation - Life of Science. InTechOpen 2013. https://doi.org/10.5772/56365

[9] Miretzky P., Cirelli A.: J. Hazard. Mater., 2010, 180, 1.

https://doi.org/10.1016/j.jhazmat.2010.04.060

[10] Hsu N-H., Wang S-L., Liao Y-H. et al.: J. Hazard. Mater., 2009, 171, 1066. https://doi.org/10.1016/j.jhazmat.2009.06.112

[11] Sereshti H., Farahani M., Baghdadi M.: Talanta, 2016, 146, 662. https://doi.org/10.1016/j.talanta.2015.06.051.

[12] Crisostomo C., Lima F., Dias R. et al.: Water Air Soil Pollut., 2016, 227, 51. https://doi.org/10.1007/s1 1270-016-2747-9

[13] Teh C., Budiman P., Shak K., Wu T.: Ind. Eng. Chem. Res., 2016, 55, 4363. https://doi.org/10.1021/acs.iecr.5b04703

[14] Kazeminezhad I., Mosivand S.: J. Magn. Magn. Mater., 2017, 422, 84. https://doi.org/10.1016/j.jmmm.2016.08.049

[15] Ronda A., Della Zassa M., Martín-Lara M. et al.: J. Hazard. Mater., 2016, 308, 285. https://doi.org/10.1016/j.jhazmat.2016.01.045

[16] Choi K., Lee S.., Ock J. et al.: Nature, 2018, 8, 1438.

https://doi.org/10.1038/s41598-018-20017-9

[17] Guo Z., Zhang J., Liu H., Kang Y.: Powder Technol., 2017, 318, 459.

https://doi.org/10.1016/j.powtec.2017.06.024

[18] Huang M., Wang Z., Liu S.: J. Environ. Chem. Eng., 2016, 4, 1555.

https://doi.org/10.1016/j.jece.2016.02.019

[19] Shashikant M., Trupti Nagendra P.: J. Inst. Eng. India Ser. A, 2015, 96, 237. https://doi.org/10.1007/s40030-015-0124-0

[20] Song D., Pan K., Tariq A. et al.: PLoS One, 2016, 11(12), e0167037. https://doi.org/10.1371/journal.pone.0167037.

[21] Kumar M., Tamilarasan R.: Arabian J. Chem., 2013, 10, S1567.

https://doi.org/10.1016/j.arabjc.2013.05.025

[22] Hsu N-H., Wang S-L., Liao Y-H. et al.: J. Hazard. Mater., 2009, 171,

1066. https://doi.org/10.1016/j.jhazmat.2009.06.112

[23] Yang J., Yu M., Chen W.: J. Ind. Eng. Chem., 2015, 21, 414.

https://doi.org/10.1016/j.jiec.2014.02.054

[24] Gueye M., Richardson Y., Kafack F., Blin J.: J. Environ. Chem. Eng.,

2014, 2, 273. https://doi.org/10.1016/j.jece.2013.12.014

[25] Cronje K., Chetty K., Carsky M. et al.: Desalination, 2011, 275, 276.

https://doi.org/10.1016/j.desal.2011.03.019

[26] Oliveira R., Hammer P., Guibal E. et al.: Chem. Eng. J., 2014, 239, 381. https://doi.org/10.1016/j.cej.2013.11.042

[27] The Gymnosperm Database 2018.

https://www.conifers.org/cu/Thuja_occidentalis.php

[28] Singanan M., Peters E.: J. Environ. Chem. Eng., 2013, 1, 884.

https://doi.org/10.1016/j.jece.2013.07.030

[29] Singanan M.: Science Asia, 2011, 37, 115.

https://doi.org/10.2306/scienceasia1513-1874.2011.37.115

[30] Mengistie A., Siva Rao T., Prasada Rao A.: Global J. Sci. Frontier Res. Chem., 2012, 12, 5. 
[31] Esposito A., Pagnanelli F., Lodi A. et al.: Hydrometallurgy, 2001, 60, 129. https://doi.org/10.1016/S0304-386X(00)00195-X

[32] Liu C., Liang X., Liu J. et al.: J. Colloid Interface Sci., 2017, 488, 294. https://doi.org/10.1016/j.jcis.2016.11.013

[33] Srivastava V., Mall I., Mishra I.: J. Hazard. Mater., 2006, B134, 257. https://doi.org/10.1016/j.jhazmat.2005.11.052

[34] Hsua N-H., Wanga S-L., Liaoa Y-H. et al.: J. Hazard. Mater., 2009, 171, 1066. https://doi.org/10.1016/j.jhazmat.2009.06.112

[35] Rangabhashiyam S., Selvaraju N.: J. Mol. Liq., 2017, 207, 39. https://doi.org/10.1016/j.molliq.2015.03.018

[36] Huang C-P., Wu M-H.: Water Res., 1977, 11, 673.

https://doi.org/10.1016/0043-1354(77)90106-3

[37] Hamadi N., Chen X., Farid M., Lu M.: Chem. Eng. J., 2001, 84, 95. https://doi.org/10.1016/S1385-8947(01)00194-2

[38] GuptaV., Ali I., SalehT. et al.: Environ. Sci. Pollut. Res., 2013, 20

1261. https://doi.org/10.1007/s1 1356-012-0950-9

[39] Rai M., Shahi G., Meena V. et al.: Res. Efficient Technol., 2016, 2, S63. https://doi.org/10.1016/j.reffit.2016.11.011

[40] Langmuir I.: J. Am. Chem. Soc., 1918, 40, 1361.

https://doi.org/10.1021/ja02242a004

[41] Frendlich H.: J. Phys. Chem., 1906, 57, 385.

[42] Sujitha R., Ravindhranath K.: J. Fluorine Chem., 2017, 193, 58.

https://doi.org/10.1016/j.jfluchem.2016.11.013

[43] Masoud M., El-Saraf W., Abdel-Halim A. et al.: Arabian J. Chem., 2016, 9, S1590. https://doi.org/10.1016/j.arabjc.2012.04.028

[44] Kilic M., Apaydin-Varol E., Pütün A.: J. Hazard. Mater., 2011, 189,

397. https://doi.org/10.1016/j.jhazmat.2011.02.051

[45] Dundar M., Nuhoglu C., Nuhoglu Y.: J. Hazard. Mater., 2008, 151, 86. https://doi.org/10.1016/j.jhazmat.2007.05.055

[46] Huang H., Tang L., Wu C.: Environ. Sci. Technol., 2003, 37, 4463. https://doi.org/10.1021/es034193c

[47] Abdel Ghani N., Hegazy A., El-Chaghaby G.: Int. J. Environ. Sci.

Technol., 2009, 6, 243. https://doi.org/10.1007/BF03327628

[48] Chen Y., An D., Sun S. et al.: Materials, 2018, 11, 269.

https://doi.org/10.3390/ma11020269

[49] Abdolali A., Ngo H., Guo W. et al.: Bioresour. Technol., 2015, 193,

477. https://doi.org/10.1016/j.biortech.2015.06.123

[50] Selvi K., Pattabi S., Kaadirvelu K.K.: Bioresour. Technol., 2001, 80, 87. https://doi.org/10.1016/S0960-8524(01)00068-2
[51] Anandkumar J., Mandal B.: J. Hazard. Mater., 2009, 168, 633. https://doi.org/10.1016/j.jhazmat.2009.02.136

[52] Garg U., Kaur M., Garg V., Sud D.: J. Hazard. Mater., 2007, 140, 60. https://doi.org/10.1016/j.jhazmat.2006.06.056

[53] Aloma I., Rodriguez I., Calero M., Blazquez G.: Desalin. Water Treat., 2014, 52, 5912. https://doi.org/10.1080/19443994.2013.812521

[54] Dakiky M., Khamis M., Manassra A., Mereb M.: Adv. Environ. Res., 2002, 6, 533. https://doi.org/10.1016/S1093-0191(01)00079-X

[55] Rangabhashiyam S., Anu N., Selvaraju N.: Res. J. Chem. Environ, 2014, 18, 30 .

Received: September 09, 2018 / Revised: November 05, 2018 / Accepted: April 08, 2019

\section{ВИДАЛЕННЯ ХРОМУ(VI) \\ З ВИКОРИСТАННЯМ КАРБОНОВОГО ПОРОШКУ 3 ЛИСТЯ THUJA OCCIDENTALIS - IЗОTEРМИ АДСОРБЦІЇ ТА КІНЕТИЧНІ ДОСЛІДЖЕННЯ}

Анотація. Досліджено адсорбиійну здатність карбонового порошку з листя туї західної (Thuja щзсcidentalis) для витіснення хрому(VI) з водних розчинів. Встановлено, щуо кількість видаленого $\mathrm{Cr}(\mathrm{VI})$ залежить від $\mathrm{pH}$, часу встановлення рівноваги, кількості адсорбенту $i$ концентрачіï $\mathrm{Cr}(V I) .3 a$ допомогою методів Фур“є-спектроскопії, скануючої електронної мікроскопії та енергодисперсійної рентгенівської спектроскопї визначено характеристики адсорбенту до $i$ після адсорбиії Cr(VI). Одержаним ізотермам адсорбиії найбільше відповідає модель Ленгмюра. Згідно кінетичних досліджень, найкращою є модель псевдо-другого порядку. Показана можсливість легкої регенерачії адсорбенту та його використання для кількох ичиклів адсорбиії/десорбиії.

Ключові слова: листя Thuja occidentalis, адсорбчія Cr(VI), ізотерми адсорбиії, кінетика. 